CENTRE for ECONOMIC

$P$ E R F O R M A N C E

CEP Discussion Paper No 839

November 2007

\title{
The Unemployment Volatility Puzzle: Is Wage Stickiness the Answer?
}

Christopher A. Pissarides 


\begin{abstract}
I study the cyclical behavior of an equilibrium search model with endogenous job creation and destruction, with focus on the model's failure to match the observed cyclical volatility of unemployment. Job creation in the model is influenced by wages in new matches. I summarize microeconometric evidence on wages in new matches and show that the key model elasticities are consistent with the evidence. Therefore explanations of the unemployment volatility puzzle have to preserve the cyclical volatility of wages. I discuss some extensions of the model that can increase cyclical unemployment volatility through mechanisms other than wage stickiness.
\end{abstract}

Keywords: wages, unemployment, wage stickiness, job creation JEL Classifications: J63, J64, E3

This paper was produced as part of the Centre's Macro Programme. The Centre for Economic Performance is financed by the Economic and Social Research Council.

\title{
Acknowledgements
}

This paper was given at the Walras-Bowley lecture, North American Summer Meetings of the Econometric Society, Duke University, June 2007. I am grateful to Per Krusell, Rachel Ngai, Michael Reiter, Christian Haefke, Gary Solon for comments and to Pedro Gomes for his research assistance. Partial funding for this study was provided by the Centre for Economic Performance, a designated research centre of the ESRC.

Christopher Pissarides is an Associate of the Centre for Economic Performance and Professor of Economics at the London School of Economics.

Published by

Centre for Economic Performance

London School of Economics and Political Science

Houghton Street

London WC2A 2AE

All rights reserved. No part of this publication may be reproduced, stored in a retrieval system or transmitted in any form or by any means without the prior permission in writing of the publisher nor be issued to the public or circulated in any form other than that in which it is published.

Requests for permission to reproduce any article or part of the Working Paper should be sent to the editor at the above address.

(C) C. A. Pissarides, submitted 2007

ISBN 978-0-85328-214-3 
Jobs in the search and matching model are characterized by monopoly rents, due to the matching frictions that give rise to search unemployment. Most of the literature assumes that the rents are shared through continuous recontracting between the firm and the worker and uses the Nash solution to the wage bargain to derive the wage rate. The outcome is the "Nash wage equation", which gives the wage rate as a linear combination of the productivity of the match and the worker's returns from search and other non market activities. Pissarides (1985) and Mortensen and Pissarides (1994) have shown that because the returns from non market activities are less cyclical than the value of labor product, wages are less cyclical and employment more cyclical in search and matching equilibrium than in a competitive market-clearing model.

Shimer (2005a), however, argues that under common parameter values the wage rate is close to being as cyclical as productivity, and so the model does not have enough power to generate the observed cyclical volatility in its key variable, the ratio of job vacancies to unemployment ("tightness"). It can explain more volatility in employment and less in wages than the competitive model does, as shown in calibrated business cycles models, but this is not enough. The volatility in unemployment that it can explain is tiny compared with the data. $^{2}$

I call the failure of the model to match the observed volatility of unemployment the unemployment volatility puzzle. I study the origins of this puzzle in a search and matching model with endogenous transitions in and out of unemployment. There is ample evidence that both transitions contribute to the cyclical volatility of unemployment, with the inflow rate contributing roughly one third to one half of the volatility of unemployment. The literature has focused mainly on the cyclical volatility of job creation (which delivers the outflow), either ignoring variations in job separations or treating them as exogenous and subject to cyclical shocks. The introduction of cyclical job separations contributes substantially to the cyclical volatility of unemployment. An important question is whether it also influences the cyclical properties of job creation and market tightness. The answer to this question depends on whether the cyclicality in job separations is the result of endogenous job destruction decisions or exogenous shocks. Endogenous job destruction along the lines of Mortensen and Pissarides (1984) has no impact on job creation, whereas exogenous job separation shocks that increase job separations in recession, of the kind analyzed by Yashiv (2006) and Mortensen and Nagypal (2007), have a negative impact on job creation. The reason for this difference is that in the case of optimal endogenous job destruction only jobs whose net productivity is close to zero are destroyed, whereas in the case of exogenous shocks all jobs, however far they are from the reservation productivity margin, have an equal probability of destruction. This difference turns out to be critical in

\footnotetext{
${ }^{1}$ The model was incorporated into the conventional real business cycle model with success, in the sense that it replicated the standard results obtained for the macro aggregates, and in addition it improved the model's performance with respect to employment. See Langot (1995), Merz (1995), Andolfatto (1976) and den Haan, Ramey and Watson (2000). See also Cole and Rogerson (1999). But none of these papers explicitly addressed the issue of unemployment volatility.

${ }^{2}$ See Hornstein, Krusell and Violante (2005) and Mortensen and Nagypal (2007) for a discussion of several issues related to this controversy.
} 
thedynamics of labor market tightness, because in the former case the additional job destruction has a very small impact on expected profits (in the limit, zero impact). Consequently, the response of job creation to cyclical productivity shocks when job destruction is endogenous is similar to its response in a model of constant job destruction rate.

The main response of the literature to the unemployment volatility puzzle was to study more closely the type of wage contract used in the model. This response is easily explained. If exogenous job separation shocks are excluded, the only mechanism that can deliver more volatility in market tightness within the canonical model is wage stickiness (see Hall and Milgrom, 2007). Moreover, as Hall (2005a) notes, more wage stickiness than implied by the Nash solution to the wage bargain can be consistent with the model, without violating rationality. There are rent division rules that are less cyclical than the Nash wage rate and which do not violate either side's participation constraints.

However, the fact that wage stickiness can be both consistent with the model and explain the unemployment volatility puzzle does not necessarily mean that it is the answer to it. I summarize empirical evidence on wage cyclicality and compare it with the solutions obtained from the model. Time series evidence, starting with the famous Keynes-Tarshis-Dunlop controversy, appeared to justify the interest in wage stickiness. ${ }^{3}$ The search and matching model has one big advantage over the competitive marketclearing model when it comes to wage stickiness: it is immune of Barro's (1977) critique that in a rational equilibrium wage stickiness should not cause employment volatility. But ultimately, whether wage stickiness is the answer to excess employment volatility or not depends on the consistency between the model and the empirical evidence. There is now a large body of econometric evidence that sheds light on the cyclical behavior of wages. I examine the findings of this literature in the context of the search and matching model.

In the search and matching model, the timing of wage payments during the job's tenure is not important for job creation. Job creation is driven by the difference between the expected productivity and the expected cost of labor in new matches. I argue that the model's Nash wage equation should therefore be compared with wages in new matches, which are a good proxy for the expected cost of labor. ${ }^{4}$ I summarize the empirical evidence about the cyclicality of wages in new matches and find that the model's Nash wage equation gets it about right: there is as much cyclicality in the empirical wage equations for new jobs as in the simple wage equation derived in the canonical model.

\footnotetext{
${ }^{3}$ See Brandolini (1995) and Abraham and Haltiwanger (1995) for surveys of the time series evidence.

${ }^{4}$ This point was also independently made by Haefke, Sonntag and van Rens (2007).
} 
The Nash wage equation implies too much cyclical volatility for the wages of ongoing employment relationships, but this cyclicality is irrelevant for job creation; getting rid of it does not increase the model's unemployment volatility. Moreover, this is true both in the United States and, perhaps more surprisingly, in the main European economies for which there are relevant data.

I conclude that wage stickiness does not receive immediate support from existing econometric studies. The equations estimated in these studies are not derived from search models, so the conclusions reached about the degree of wage stickiness relevant to search models are based on indirect inference. More direct estimates of structural search models would provide stronger support but they are not yet available. But given the weak support for wage stickiness in the econometric studies, plausible explanations of the unemployment volatility puzzle should not be relying on a sticky-wage transmission mechanism. Their wage equations should be consistent with the observed proportional (or near-proportional) relation between labor productivity and wages. I discuss some extensions of the model that can yield more volatility in unemployment without violating wage flexibility.

Hagedorn and Manovskii (2006) have argued that nonmarket returns are high, about $95 \%$ of market returns for the typical worker, and if this is so the model can calibrate the observed cyclical volatility in tightness with near-proportional wages. The model is subject to two other criticisms, however. Costain and Reiter (2005) note, in a paper that anticipated to some extent both the Shimer (2005a) critique and the Hagedorn and Manovskii (2006) response, that if nonmarket returns are high the response of unemployment to labor market policy, in particular unemployment insurance, is too large. Hall and Milgrom (2007) also note that the Hagedorn and Manovskii calibrations imply far too high a labor supply elasticity, given empirical estimates. Hall and Milgrom (2007) in their paper change the wage bargain to one of strategic (sequential) bargaining with delay costs. They show that the model delivers the required unemployment volatility and avoids unrealistic wage stickiness. I show here that a similar result can be obtained with the Nash wage equation when there are wage negotiation costs of the magnitude that they assume. But as with the Hagedorn and Manovskii model, the response of unemployment to unemployment insurance is also too high, though less so than in Hagedorn and Manovskii's model.

I briefly discuss some other extensions to the model, in particular asymmetric information, on-the-job search and nonuniform productivity shocks, which can increase the 
volatility of unemployment with Nash wages. As productivity shocks are not likely to be the only driving force of the volatility in unemployment, future work needs to find also other cyclical driving forces. Aggregate demand is one driving force that is attracting a lot of interest in the recent literature but a discussion of models of aggregate demand is beyond the scope of this paper.

In the remainder to this paper I first briefly discuss some issues in the dynamic evolution of unemployment, in particular the role of movements in and out of the labor force and flows between employment and unemployment (section 1). Following this, I derive the key cyclical elasticities of tightness and wages from a canonical search and matching model with endogenous job finding and job separations (sections 2 and 3). I then survey the econometric evidence on wages and show that the estimated elasticities match the model's calibrated elasticities (section 4). I finally discuss the implications of my findings for wage modeling and for the cyclical dynamics of unemployment (section $5)$

\section{What drives the dynamics of unemployment?}

The approach that I follow in this paper is to derive the impact of cyclical shocks on unemployment by modeling the flows in and out of unemployment. Two questions immediately arise. First, do we lose essential generality if we ignore transitions between unemployment and out of the labor force, and second, should we model cyclicality in both the flows in and the flows out of unemployment? The answer to these questions for the conventional rate of unemployment is no to the first one and yes to the second.

The flow rates between activity and inactivity show some cyclicality but several investigators have concluded that they do not contribute substantially to the cyclical volatility of unemployment (see Shimer, 2005b, Hall, 2005b, Braun, De Bock and DiCecio 2006, Elsby, Michaels and Solon 2007, and Fujita and Ramey 2007). The rate of inactivity itself is nearly acyclical and the correlation between the cyclical components of the rates of unemployment and employment is -0.95 . I therefore focus on a simple two-state model, with workers moving between the state of unemployment and employment in response to shocks. This is also the focus of the canonical model that has recently come under scrutiny.

In a two-state model, I define the change in the unemployment rate,

$$
\Delta u_{t}=f_{i t}\left(1-u_{t}\right)-f_{o t} u_{t}
$$


where $f_{i t}$ is the flow rate between employment and unemployment during period $t$ (the inflow, defined as the total number of workers who move from employment to unemployment divided by the number of employed workers) and $f_{o t}$ is the flow rate in the other direction (the outflow, defined as the number of workers who move from unemployment to employment divided by the number of unemployed workers). If the two flow rates remain constant for a sufficiently long time unemployment converges to the steady-state rate,

$$
u=\frac{f_{i}}{f_{i}+f_{o}} .
$$

With quarterly data on unemployment stocks and flows, constructed under the assumption that $f_{i}$ and $f_{o}$ are constant during the quarter, the unemployment rate obtained from (2) is virtually indistinguishable from the actual unemployment rate. ${ }^{5}$ I therefore use (2) as my unemployment equation throughout this paper. Taking first differences of (2) I find that the change in the rate of unemployment is approximately given by

$$
\Delta u_{t}=u_{t}\left(1-u_{t}\right)\left(\frac{\Delta f_{i t}}{f_{i t}}-\frac{\Delta f_{o t}}{f_{o t}}\right)
$$

Figure 1 shows the contribution of each flow rate to the change in unemployment. The flow rates are derived from the quarterly job finding and job exit probabilities constructed by Shimer (2005b) and available online, and the two series shown in Figure 1 respectively are $u_{t}\left(1-u_{t}\right) \Delta f_{i t} / f_{i t}$ and $u_{t}\left(1-u_{t}\right) \Delta f_{o t} / f_{o t}$. Clearly, both rates contribute to the change in the unemployment rate. Their correlation coefficient is -0.55 so on average their contribution is in the same direction. A consensus estimate in the literature for the contribution of the inflow rate lies between one third and one half of the total. ${ }^{6}$

The recent literature has either ignored the inflow rate when studying the dynamics of unemployment, or treated shocks to the inflow rate as one of the exogenous forces driving changes in the outflow rate. But because more low-productivity jobs are destroyed in

\footnotetext{
${ }^{5}$ See Shimer (2005b), where constructed quarterly time series data for the flows are also available for downloading, http://robert.shimer.googlepages.com/flows. The same appears true of economies with longer durations in each state, as in pre-1980s Britain. See Pissarides (1986).

${ }^{6}$ See the references earlier cited in this section. Of course, the question of the cyclicality of unemployment flows is quite distinct from the question of the cyclicality of job flows. Concerning especially the flow out of jobs, one can distinguish between the flow of workers from employment to unemployment (the focus of this paper), the flow of workers out of jobs (the separation rate) and the flow of jobs from activity to inactivity (the job destruction rate). See for example Davis, Haltiwanger and Schuh (1996) and Hall (2005b). Because of the abstractions of the model, I often refer to the unemployment outflow rate as the job creation or job finding rate and to the unemployment inflow rate as the job destruction or job separation rate.
} 
recession (e.g., Solon, Barsky, and Parker, 1994), at least some part of job separations is driven by endogenous decisions in response to aggregate productivity shocks. If all job destruction were driven by exogenous separation shocks the jobs destroyed in recession would be a random draw from the productivity distribution. It makes a lot of difference to the volatility results whether cyclical separations are driven by exogenous shocks or by endogenous job destruction. In the model that follows I assume that there are both exogenous separations shocks and endogenous job destruction, although I attribute the cyclicality of the inflow rate to endogenous job destruction.

\section{The canonical model with endogenous and exoge- nous job destruction}

In the canonical model (Mortensen and Pissarides, 1994) agent decisions are made with full awareness of the future path of variables. Vacancy creation, reservation (acceptance) values and wages are jump variables but employment and unemployment are state variables. The objective of the exercise is to compare the second moments of the endogenous variables, in particular unemployment, vacancies and wages, with the second moment of labor productivity, the canonical model's driving force. But because the matching flows are large, and there is a lot of persistence in productivity when compared with the speed at which unemployment approaches its steady state, there is no loss of generality if we derive the cyclical results from comparative static exercises with a continuous-time model that compare steady states at different realizations of labor productivity.

Decisions take place as follows. At any time $t$ the economy inherits employment $1-u$ and unemployment $u$. Each employed position is characterized by productivity $p x$ and a wage rate $w(x)$, with $p>0$ a proportional economy-wide productivity parameter and $x \in[0,1]$ a match-specific parameter. A randomly-selected fraction $s \geq 0$ of jobs break up for exogenous reasons and another randomly-selected fraction $\lambda \geq 0$ receive a productivity shock that moves each job's idiosyncratic productivity to some other value $x^{\prime} \in[0,1]$ drawn from the c.d.f. $G\left(x^{\prime} \mid x\right)=G\left(x^{\prime}\right)$. All persistence in idiosyncratic

productivities is in the arrival process $\lambda$, and at the individual level the process has no memory.

Each one of the matches that receives a productivity shock has the option of either continuing production at $p x^{\prime}$ or closing down. If the firm and worker decide to continue, a new wage $w\left(x^{\prime}\right)$ is agreed and production takes place; otherwise the job is destroyed, 
the worker enters unemployment and the firm gets zero payoff.

The workers who are unemployed and the ones who lose their jobs participate in matching with a measure of vacancies $v$, determined by firms' profit-maximizing decisions. The outcome is a measure $m$ of new job matches which can produce with maximum productivity $p$. Matching takes place according to a concave constant-returns aggregate matching function $m(u, v)$. Once a new match takes place a wage $w(1)$ is agreed between the firm and worker and production begins.

I derive first the flows in and out of unemployment, and re-write equation (2) for the canonical model. The flow out of unemployment is the matching rate which, when divided by employment, is also the empirical job creation rate. The flow into unemployment is the sum of job destruction and exogenous breakups.

The matching rate is written more conveniently in terms of the average transition rate for an individual worker, $m(1, v / u)$. I define tightness $\theta \equiv v / u$ and $q(\theta)$ as the transition rate for a vacancy, so $m(1, v / u)=\theta q(\theta)$. The elasticity of $q(\theta)$ is denoted $-\eta(\theta) \in(-1,0)$. Job destruction is driven by a reservation productivity rule on the idiosyncratic productivity parameter. Let $R$ be the reservation productivity, such that existing jobs remain active if and only if $x \geq R$. In the notation of equation (2), $f_{i}=$ $s+\lambda G(R)$ and $f_{o}=\theta q(\theta)$, so the rate of unemployment that equates the matching rate with job separations is given by

$$
u=\frac{s+\lambda G(R)}{s+\lambda G(R)+\theta q(\theta)} .
$$

\subsection{Job creation and job destruction}

The utility function of both workers and firms is linear, but unemployed workers enjoy some imputed income $z$ during unemployment, which has to be given up when they take a job. The job creation decision is initiated by an employer when he posts a vacancy, at a flow cost $c$ for the duration of the vacancy. In contrast, the equilibrium reservation product, $R$, reflects the decisions of both parties to continue an existing employment relationship, if necessary through redistribution of the future surplus from the job. I assume that whatever the wage determination mechanism, no jobs that can survive through redistribution are destroyed, namely, that job destruction does not violate joint rationality. In a decentralized equilibrium it also satisfies individual rationality through wage redistributions. For a given wage determination mechanism, a search equilibrium is a pair $(R, \theta)$ that simultaneously solves the job creation and job destruction conditions. 
For the moment I invoke the existence of a wage mechanism $w(x)$ for each job with idiosyncratic productivity $x$, with non-negative first derivative (I suppress for convenience the dependence on $p$ and any other variable). A continuing match with productivity $x$ has capital value $J(x)$ to an employer that solves the following asset pricing equation

$$
r J(x)=p x-w(x)+\lambda \int_{R}^{1}[J(n)-J(x)] d G(n)-[\lambda G(R)+s] J(x)
$$

where $r$ represents the risk free interest rate and the assumption is made that a destroyed job has zero value to the employer. The return on the capital value of an existing jobworker match to the employer is equal to current profit plus the expected capital gain or loss associated with the arrival of a productivity shock. Taking expected values of (5) and denoting in general $\bar{J}=E(J(x) \mid x \in[R, 1])$, we obtain the expected value of a continuing match,

$$
\bar{J}=\frac{p \bar{x}-\bar{w}}{r+s+\lambda G(R)} .
$$

A new vacancy leads to a match at maximum idiosyncratic productivity so it satisfies the asset pricing equation

$$
r V=-c+q(\theta)[J(1)-V] .
$$

Vacancies are a jump variable and vacancy creation exhausts all available profits, so the job creation condition is

$$
V=0 \Longleftrightarrow J(1)=\frac{c}{q(\theta)}
$$

From (5) and (6) we can write

$$
J(1)=\frac{p-w(1)-(p \bar{x}-\bar{w})}{r+s+\lambda}+\bar{J} .
$$

The first term on the right shows the excess profit made by the firm in the initial period of the match, when productivity is at its maximum. That period ends at rate $s+\lambda$. After the arrival of the first shock the job makes on average mean profit, $\bar{J}$.

Because job destruction is a jointly rational decision we need to derive the value of the job to both employer and worker before we can write the optimality condition. Let $S(x)$ be the joint gross return from a match with job-specific productivity $x$, and let $U$ be the value of unemployment to the worker. The value of a vacancy to the firm is $V$ but if the match is destroyed because of a negative shock it is lost. $S(x)$ satisfies the Bellman equation

$$
r S(x)=p x+\lambda \int_{R}^{1}[S(n)-S(x)] d G(n)-(s+\lambda G(R))(S(x)-U) .
$$


The jointly-rational job destruction condition is

$$
S(R)-U=0
$$

The common practice in the literature is to use the Bellman equations in conjunction with (8) and (11) to arrive at two equations in $\theta$ and $R$, each of which has elements of both the job creation and job destruction rules. I take a different route here, which separates completely the job creation and job destruction decisions. I derive an equation for $\theta$ from (8) and the Bellman equations, without making use of the job destruction condition, and one for $R$ from (11) and the Bellman equations without making use of the job creation condition.

From (8), (6) and (9) I obtain the job creation condition

$$
\frac{c}{q(\theta)}=\frac{p-w(1)-(p \bar{x}-\bar{w})}{r+s+\lambda}+\frac{p \bar{x}-\bar{w}}{r+s+\lambda G(R)} .
$$

To derive the job destruction condition I note that (10) and (11) imply

$$
S(x)-U=\frac{p(x-R)}{r+s+\lambda} \quad \forall x \in[R, 1]
$$

so the job destruction condition becomes,

$$
p R+\frac{\lambda p}{r+s+\lambda} \int_{R}^{1}(x-R) d G(x)=r U .
$$

$r U$ is the "permanent income" of unemployed workers, the sum of unemployment income and the expected returns from search. Because of the assumption of joint rationality in job destruction, own wages do not influence job destruction but wages elsewhere do through their impact on the expected returns from search. I will postpone discussion of the value of $r U$ until the next section.

\subsection{Wage determination}

The canonical model assumes that wages share the surplus from the job in fixed proportions at all times. If we let $W(x)$ be the worker's expected returns form holding a job with idiosyncratic productivity $x$ wages solve

$$
W(x)-U=\beta(S(x)-V-U) \quad \forall x \in[R, 1], \beta \in[0,1),
$$


noting that for as long as the job is active the firm can get a return $V$ from it should the worker separate. This sharing rule can be derived as the solution to a generalized Nash bargaining problem

$$
w(x)=\arg \max \left\{[W(x)-U]^{\beta}[S(x)-W(x)-V]^{1-\beta}\right\} .
$$

Given (5) and the equivalent equation satisfied by $W(x)$ :

$$
r W(x)=w(x)+\lambda \int_{R}^{1}[W(n)-W(x)] d G(n)-[\lambda G(R)+s][W(x)-U],
$$

the wage equation also satisfies,

$$
w(x)=r U+\beta(p x-r U-(r+s+\lambda G(R)) V) .
$$

This equation makes clear that there are three separate mechanisms through which a shock to productivity is transmitted to wages. First, there is a direct effect that is due to the sharing assumptions, the $p x$ term in (18); and second and third, there are indirect effects that transmit shocks to $p$ through changes in the reservation values of the firm and the worker. The controversy surrounding wages centres on the role of the reservation values in wage determination, which in the Nash wage rule have maximum impact because they define the "threat points" of the firm and the worker. ${ }^{7}$

The solution commonly found in the literature is derived from (18) by making use of the job creation and job destruction conditions to substitute out the reservation values:

$$
w(x)=(1-\beta) z+\beta(p x+c \theta) \quad \forall x \geq R .
$$

The job creation and job destruction conditions with this wage rule can be respectively represented by a downward-sloping and an upward-sloping curve in $(R, \theta)$ space. The main criticism made of this wage equation is that it makes wages too responsive to the cycle. But this conclusion is not usually reached by examining the relation between the wage equation of the model and wage volatility over the cycle in the data, but by showing that a less responsive wage equation can reconcile the high volatility of vacancies and unemployment with the low volatility of productivity. Examination of (12) shows that if there are no exogenous shocks to job separations, which can drive changes in the

\footnotetext{
${ }^{7}$ Note that because the vacancy value is lost at rate $s+\lambda G(R)$, whereas the value of unemployment is never lost, the value of a vacancy is discounted at rate $r+s+\lambda G(R)$ whereas that of unemployment only at $r$.
} 
discount rate, wage stickiness is the only mechanism that can reconcile the volatility of the job finding rate with the model.

The question that I am focusing on here is whether the estimated wage equations in the literature shed light on the cyclical volatility of wages derived from (18). An issue here is whether the estimated wage equations are of the unconstrained structural form in (18), or whether the estimated elasticities have implicit in them the restrictions in the other two equilibrium conditions, $V=0$ and $S(R)-U=0$. Given that the econometric estimates are obtained from real data, micro or macro, from economies that may temporarily be out of equilibrium, and more importantly that the regressions include several institutional and other variables, a comparison with the unconstrained elasticities of the model would seem more appropriate. But it turns out that the derived total elasticity of wages with respect to productivity is the same irrespective of the equation used to derive it. I will derive the elasticities implied by the model after I solve the model numerically.

\section{Solving the model}

\subsection{Parameters and steady-state solutions}

The model has three equations in three unknowns, $\theta, R, w$, all of which are jump variables that instantaneously reach their equilibrium. The three equations for this solution are (12), (14) and (19). Given the solutions for these unknowns, unemployment is given by the Beveridge equation, (4), which I treat as representing the actual unemployment rate. I solve the model for monthly data.

Note that under the Nash wage equation, and making use of the job creation condition,

$$
\begin{aligned}
r U & =z+\theta q(\theta)[W(1)-U] \\
& =z+\theta q(\theta) \frac{\beta}{1-\beta}[J(1)-V] \\
& =z+\frac{\beta}{1-\beta} c \theta .
\end{aligned}
$$

So in equilibrium the job destruction condition (14) satisfies,

$$
p R+\frac{\lambda p}{r+s+\lambda} \int_{R}^{1}(x-R) d G(x)=z+\frac{\beta}{1-\beta} c \theta .
$$


As in Mortensen and Pissarides (1994) I assume that the idiosyncratic productivity distribution is uniform in the range $[\gamma, 1]$ :

$$
G(x)=\frac{x-\gamma}{1-\gamma}
$$

It follows that

$$
\begin{aligned}
\int_{R}^{1} x d G(x) & =\frac{1-R^{2}}{2(1-\gamma)} \\
\bar{x} & =\frac{1+R}{2}
\end{aligned}
$$

The matching function is assumed to be Cobb-Douglas $m=m_{0} u^{\eta} v^{1-\eta}$, with unemployment elasticity $\eta=0.5$ (see Petrongolo and Pissarides, 2001). Following common practice, I also assume $\beta=0.5$, which internalizes the search externalities. ${ }^{8}$ The job finding rate is $\theta q(\theta)=m_{0} \theta^{0.5}$. The sample mean for $\theta$ in 1960-2006 was 0.72 , derived by making use of JOLTS data since December 2000 and the Help-Wanted Index adjusted to the JOLTS units of measurement before then. Shimer's (2005b) monthly transitions data (under the assumption that monthly transition rates are constant within the quarter) give a mean value for 1960-2004 of 0.594 for the job finding rate and 0.036 for the job separation rate. The implied unemployment rate is $5.7 \%$, very close to the actual mean. I make use of the mean job finding rate and mean tightness value to solve for $m_{0}$. The result is $m_{0}=0.7$.

Distinguishing between the exogenous component of the separation rate and the endogenous is not easy. I identify $\lambda G(R)$ with worker displacement and $s$ with other separations that lead to entry into unemployment. Farber (1997) reports that over a three-year period about $12 \%$ of workers experience displacement, whereas the job destruction rate over a comparable period, as calculated by Davis and Haltiwanger (1999), is $20 \%$. I therefore assume that $\lambda G(R)$ is on average $12 / 20$ of all job destruction. The quarterly rate of job destruction is $8-9 \%$, which gives a quarterly value for $\lambda G(R)$ of 0.051 . I therefore set the monthly mean of $\lambda G(R)$ at 0.017 and consequently $s=0.019$. However, results are virtually identical if I set $\lambda G(R)$ equal to $12 / 20$ of the monthly rate of 0.036. With $r=0.004$, I obtain $r+s=0.023$ as one component of the discount rate.

\footnotetext{
${ }^{8}$ See Hall and Milgrom (2007) for a different motivation for $\beta \cong 0.5$ and Hagedorn and Manovskii (2006) for reasons to select a much smaller value for $\beta$. As with $\beta$, the elasticity $\eta$ plays some role in the quantitative solutions of the model but within the small range of $0.5-0.6$, which conforms to the empirical estimates reported in Petrongolo and Pissarides (2001) the solutions are robust to it. In the version presented in $2006 \mathrm{I}$ used $\beta=\eta=0.6$ with virtually identical results for the elasticities.
} 
For $\lambda$ I choose $\lambda=0.1$, which implies that on average there is a productivity shock every 10 months. Of course, no direct evidence can be obtained on this frequency. What guided me in the choice of $\lambda$ is the fact that the biggest impact that different values of $\lambda$ have in the model is on the elasticity of separations with respect to productivity, with lower values giving smaller elasticities. The value of $\lambda$ also has an impact on wage inequality, which is not an issue at present, but it has a very small impact on the elasticities of tightness and wages with respect to productivity. The number that I chose implies a separations elasticity that is close to the figure observed in the United States. With this assumption and (22) I obtain a value for $\gamma$

$$
\gamma=1.275 R-0.275
$$

The average level of productivity in this economy is $p \bar{x}$. I assume that $z / p \bar{x}=0.71$, as in Hall and Milgrom (2007), and normalize $p=1$, which gives

$$
z=0.355(1+R)
$$

There is only one other parameter that needs to be specified, the cost of maintaining a vacancy, $c$. I choose the value that satisfies the zero-profit condition (12) at sample means:

$$
c=0.384-0.029 R \text {. }
$$

I use these parameter values in (21) to obtain a benchmark value for $R$ at the sample mean $\theta=0.72$, which is $R=0.893$. This value and the expressions previously given yield the parameter values shown in Table 1 . The vacancy cost flow is about eleven days of average output. However, the vacancy cost is paid for $1 / q(\theta)=1.2$ months on average, whereas the job lasts 28 months on average, so ignoring discounting the firm's recruitment cost is on average only $1.5 \%$ of total expected output.

Some of the model solutions at these parameter values are shown in Table 2. Wages at low productivity levels exceed the firm's return from production and they are below the worker's reservation wage, ${ }^{9}$ but the job is not destroyed because of its option value. Wages appear "sticky" in relation to the job-specific productivity, with a range of $0.911-$ 0.965 compared with a productivity range of $0.893-1$. The percentage gain in flow receipts when a worker accepts a job is substantial, $100(.965 / .672-1)=43.5 \%$. But the "permanent income" of employed workers is only marginally above the "permanent

\footnotetext{
${ }^{9}$ The reservation wage is conventionally defined as $r U$. However, given the model solutions it is a misnomer in this case.
} 
Table 1: Parameter values, quarterly data

\begin{tabular}{cccc}
\hline \hline Parameter & value & description & target \\
\hline$r$ & 0.004 & interest rate & data \\
$\lambda$ & 0.1 & shock arrival & separations elasticity \\
$\gamma$ & 0.872 & lower prod. support & 40\% of job destruction \\
$s$ & 0.019 & exog. separations & rest of separations \\
$z$ & 0.672 & leisure and UI comp. & Hall-Milgrom $(2007)$ \\
$c$ & 0.357 & vacancy cost & mean $\theta$ \\
$m_{0}$ & 0.7 & matching fn. scale & job finding probability \\
$\eta$ & 0.5 & matching fn. elasticity & Petrongolo-Pissarides $(2001)$ \\
$\beta$ & 0.5 & share of labor & $\beta=\eta$ (efficiency) \\
\hline \multicolumn{3}{c}{ Data, mean values } \\
\hline$m_{0} \theta^{1-\eta}$ & 0.594 & mean $v / u$ (tightness) & JOLTS, HWI \\
\hline$s+\lambda G(R)$ & 0.036 & job separations prob. & Shimer $(2005 \mathrm{~b})$ \\
\hline
\end{tabular}

Table 2: Model solutions, Nash wages

\begin{tabular}{ccc|ccc}
\hline \hline Variable & description & solution & Variable & description & solution \\
\hline$R$ & reservation prod. & 0.893 & $V$ & value vacancy & 0 \\
$\bar{x}$ & mean prod. & 0.947 & $J(1)$ & value new job & 0.433 \\
$w(1)$ & max wage & 0.965 & $J(\bar{x})$ & value mean job & 0.216 \\
$\bar{w}$ & mean wage & 0.938 & $J(R)$ & value res. job & 0 \\
$w(R)$ & min wage & 0.911 & $W(1)-U$ & gain, new job & 0.433 \\
$\lambda G(R)$ & job destruction & 0.017 & $W(\bar{x})-U$ & gain, mean job & 0.216 \\
$r U$ & value unempl. & 0.929 & $W(R)-U$ & gain, res. job & 0 \\
\hline
\end{tabular}

income" of unemployed workers, a consequence of the assumption of infinite horizons, short unemployment durations and uniform unemployment incidence.

\subsection{Elasticities}

In order to compute the impact of productivity shocks on the model's unknowns I calculate the model's solutions for a $1 \%$ higher common productivity $p .{ }^{10}$ Higher productivity has two effects, it reduces the reservation productivity and increases tightness. The former reduces the mean value of the idiosyncratic productivity of active jobs, so the observed rise in labor productivity is less than the $1 \%$ rise in $p$. This effect cor-

\footnotetext{
${ }^{10}$ The computed elasticities are virtually identical for a $1 \%$ or a $2 \%$ change in $p$. The standard deviation of labor productivity in the sample is $2 \%$ but this is not the same as the standard deviation of $p$ because of changes in the composition of jobs. The computed elasticities are also virtually identical to the ones obtained by differentiating first the expressions of the model and then computing their values.
} 
Table 3: Impact of 1 percent higher common productivity on equilibrium outcomes

\begin{tabular}{ccc|cc}
\hline \hline Variable & description & solution & elasticity w.r.t. $p$ & elasticity w.r.t. $p \bar{x}$ \\
\hline$R$ & reservation prod. & 0.893 & -0.088 & -0.092 \\
$\theta$ & tightness & 0.745 & 3.47 & 3.62 \\
$\bar{x}$ & mean prod. & 0.946 & -0.04 & - \\
$w(1)$ & max wage & 0.974 & 0.987 & 1.03 \\
$\bar{w}$ & mean wage & 0.947 & 0.965 & 1.01 \\
$w(R)$ & min wage & 0.920 & 0.943 & 0.984 \\
$\lambda G(R)$ & job destruction & 0.016 & -3.67 & -3.83 \\
$s+\lambda G(R)$ & separations & 0.035 & -1.72 & -1.79 \\
$r U$ & value unempl. & 0.938 & 0.97 & 1.01 \\
\hline
\end{tabular}

responds to a "composition" change, but because we have assumed a $\lambda$ that does not imply much inequality, our estimates show that the mean productivity $p \bar{x}$ goes up by $0.96 \%$ in response to the $1 \%$ rise in $p$. The higher tightness increases job creation but it also increases wages. In Table 3 I give the solutions for $p=1.01$ and the "elasticities" of each variable with respect to common productivity $p$ and the (endogenous) mean labor productivity $p \bar{x}$. The elasticities are calculated as the log change in the variable in question divided by the log change in either $p$ or $p \bar{x}$.

The computed response of the job separation rate to productivity is close to the one observed in the data but this correspondence is largely due to our choice of the free parameter $\lambda$. In US data the ratio of the standard deviations of job separations and labor productivity is $0.075 / 0.020=3.75$ and their correlation coefficient -0.524 (see Shimer, 2005a, Table 1), which gives a partial impact of productivity of $-1.96 .^{11}$

The elasticity that has attracted most attention in the literature is the one of tightness, which drives the job creation rate and the exit from unemployment. In the canonical model this is 3.62. In his original critique of the search and matching model Shimer (2005a) finds an elasticity of 1.71. The target for this elasticity is 7.56 , which would be the regression coefficient in a simple regression with tightness as dependent variable and productivity as independent. ${ }^{12}$ Virtually the only reason for the difference in the

\footnotetext{
${ }^{11}$ In the data the job destruction rate has higher variance than the employment-unemployment transition, because quitting into unemployment is procyclical. In this paper we assumed that the job destruction rate (or more accurately, displacement) is the only cyclically-sensitive component of the employment-unemployment transition, so the difference in the model between the cyclicality of the job destruction rate and the overall transition is smaller than it is in the data.

${ }^{12}$ Shimer (2005a) sets the target at 19.1, which is the ratio of the standard deviations of tightness and productivity. But this should be the target if there were no measurement or other random errors in the two variables and if no other shocks influenced tightness. To get the 7.56 target I multiply by their
} 
two elasticities is due to $z$. The bigger $z$ in our calibration has an impact because it reduces the firm's steady-state profit and so implies that cyclical shocks have a bigger proportional impact on profits. When job destruction is held constant, the change of $z$ from 0.4 (Shimer's number) to our 0.71 increases the elasticity in our version of the model from 1.73 to 3.62 .

I draw three conclusions from the results in Table 3. First, breaking the volatility of unemployment into the volatility of the inflow rate and the outflow rate, the "puzzle" of high volatility can be traced to the low volatility of the outflow rate (or job finding rate) in the canonical model. This is partly because in order to properly quantify the impact of productivity shocks on endogenous job destruction we need information about the distribution of idiosyncratic shocks that we do not have at present. Feasible parameter values for this distribution can deliver as much volatility in this rate as there is in the data, but of course this does not necessarily imply that these parameters are also the ones characterizing the real economy.

Second, the responsiveness of the job finding rate to the productivity shocks in the canonical model is the same as its responsiveness in a simpler model with constant job destruction. Endogenous job destruction does not contribute to more volatility in the job finding rate. This result may be counter-intuitive, because intuitively, if there is more job destruction, the expected duration of jobs is shorter, so firms should be less willing to create jobs. But this intuition fails when the job destruction is endogenous because of the envelope property characterizing optimal job destruction. In the limit, when the productivity shocks are infinitesimally small, the jobs that are destroyed when there is a negative productivity shock are the ones whose productivity is the reservation one, i.e., whose expected profit is zero. The firm is indifferent between making these jobs active or inactive.

Mortensen and Nagypal (2007) and Yashiv (2006) argue that job destruction shocks can also increase the volatility of job creation, because in their models the shocks are exogenous. In terms of our notation, their shocks are exogenous changes in $s$. Now, looking at the unemployment equation (4), it is clear that as far as the volatility in unemployment is concerned, it should not matter if the shocks are in $s$ or in the endogenous fraction $G(R)$. They both have the same impact on $u$. But looking at the job creation condition $V=0$, the exogenous changes in $s$ have a large impact on $V$ at given tightness, because they influence the rate at which future profits are discounted.

correlation coefficient. See also the prenultimate section for more discussion of other driving forces. 
A rise in $s$ within the plausible range has a large impact on the discount rate because it is a big component of it. But endogenous changes in $G(R)$ have no impact on $V$ at given tightness if they are small enough. Changes in endogenous job destruction have two effects on expected profits that work in opposite directions. They change both the discount rate and the conditional mean of expected future output. A rise in endogenous job destruction raises the discount rate, which reduces the present-discounted value of future profits at given profit flow, but also raises the expected profit flow because the jobs that are destroyed are in the left tail of the productivity distribution. At the optimum point the two effects exactly cancel each other out. Exogenous separation shocks have only the discounting effect, because the additional jobs destroyed are a random selection from the productivity distribution.

Finally, the equilibrium response of wages to productivity shocks is very close to proportionality. This encouraged the search for alternative wage determination mechanisms but whether proportionality is reasonable or not depends on the data. It is clear, however, that (a) the model can accommodate sufficient wage stickiness without violating rationality, because of the local monopoly rents created by a job match (Hall's, 2005a, point), and (b) even small amounts of wage stickiness can make a lot of difference to the response of job creation to productivity shocks. I next take a closer look at this final claim.

\subsection{The Role of wage stickiness}

I now look further into the role of wage stickiness in the volatility of the job finding rate in a simpler model with constant job destruction. The results are the same as in the endogenous job destruction model, because job destruction is jointly rational, namely, wage stickiness is not allowed to cause "involuntary" job destruction. Suppose then that $\lambda=0$ and recalibrate $s$ to be equal to the whole of job separations, $s=0.036$. The asset value of a job is now common across all jobs and denoted $J$. It satisfies the Bellman equation

$$
r J=p-w-s J
$$

Of course, wages are also common across all jobs, so the zero profit condition yields

$$
\frac{p-w}{r+s}=\frac{c}{q(\theta)} \text {. }
$$

Wages are determined by the Nash equation

$$
w=\arg \max (W-U)^{\beta}(J-V)^{1-\beta}
$$


given the other standard Bellman equations. The result is as before, (19) with $x=1$.

Let now the elasticity of $\theta$ with respect to $p$ be $\varepsilon_{\theta}$ and the one of wages $\varepsilon_{w}$. From (29),

$$
\varepsilon_{\theta}=\frac{1}{\eta} \frac{p-\varepsilon_{w} w}{p-w} .
$$

If $\varepsilon_{w}=1, \varepsilon_{\theta}=1 / \eta=2$, essentially the Shimer critique. Obviously, reducing $\varepsilon_{w}$ increases $\varepsilon_{\theta}$. As we noted before, in this model $\varepsilon_{\theta}=3.62$, achieved by a wage elasticity $\varepsilon_{w}=0.986$ and a solution for $w=0.983$. How much wage stickiness is needed to hit the required $\theta$ elasticity of 7.56 ?

As is clear from (31), the answer to this question depends critically on how close $w$ is to $p$. I rearrange (31) to obtain:

$$
\varepsilon_{w}^{*}=\frac{p}{w}-\varepsilon_{\theta} \frac{\eta(p-w)}{w} .
$$

Using the same solution for $w$ as in the model with the Nash wage equation and setting $\varepsilon_{\theta}=7.56$ gives $\varepsilon_{w}^{*}=0.885$. For solutions that yield a $w$ further away from $p$ the required wage elasticity is less. In this simple model the distance of $w$ from $p$ is dictated largely by $z$, so its role is crucial in computing the wage elasticity needed to deliver the required volatility in the job finding rate. For $z=0.4$, the required wage stickiness is $\varepsilon_{w}^{*}=0.758$, whereas for $z=0.9$ the computed Nash wage elasticity of 0.974 delivers even more volatility in $\theta$ than the required elasticity (essentially Hagedorn and Manovskii's point).

\section{What do wage equations show?}

The first and most influential studies of cyclical wage stickiness were based on time series regressions derived either from single-equation or small aggregate models of the economy. ${ }^{13}$ These studies were stimulated by the controversy between Keynes, his followers and his critics (in particular Dunlop and Tarshis) about the role of wage stickiness in the business cycle. They continued well into the 1980s. Their findings are mixed. Results are sensitive to the specification used and to the sample period. Time series data before 1960 show less wage cyclicality than data since 1970. A robust finding of these studies is that whichever way the cyclicality of wages goes, it is not very much; i.e., wages are

\footnotetext{
${ }^{13}$ This is not a comprehensive survey of the empirical literature but a selective discussion of results that bear directly on the model. For good surveys of the main issues and the main empirical findings see Brandolini (1995) and Abraham and Haltiwanger (1995).
} 
sticky, and may exhibit a limited degree of pro- or counter-cyclicality depending on time period, deflator used, coverage and other issues.

These time-series studies have been extremely influential in shaping the opinions of macroeconomists about wage stickiness, giving rise to a consensus that made it into most textbooks. But their findings are not relevant to the search and matching model. The search and matching model draws a sharp distinction between the cyclicality of wages in new matches and the wages of ongoing relationships. The outcome that matters for job creation is the share of a new match claimed by the firm. Given this share, the timing of wage payments is irrelevant (see also Shimer, 2004). But even if the distinction between new and old matches is overlooked, the search and matching model is concerned with the cyclicality of wages in individual matches, not the average in the economy as a whole. In this connection there appears to be a strong counter-cyclical bias in wages in the aggregate studies, at least during the 1970s and 1980s. ${ }^{14}$ The bias is due mainly to the fact that low-wage, low-skill workers bear the brunt of cyclical adjustments and so their weight in aggregate data is bigger in cyclical peaks than in troughs.

In view of this, the results of panel regressions of individual workers, or matches, are more relevant to the search and matching model than the results of aggregate studies. These results favor strong procyclicality of wages. ${ }^{15}$ Panel studies typically run a wage log-change regression for the individuals in their panel on a set of personal characteristics, such as tenure, experience and education, regional or industry dummies and time dummies. The coefficients on the time dummies are then used in a second regression as the dependent variable with a time trend and a cyclical indicator variable as regressors. Tables 4 and 5 summarize the results of individual studies of wage behavior, focusing on studies that draw a distinction between continuing jobs and new matches. The tables give the coefficient estimated in the second regression for the cyclical indicator, which is the change in national unemployment. The numbers given are the annual percentage change in wages when national unemployment falls by 1 percentage point from one year to the next. Figure 2 shows the estimated cyclical component for wages in new and continuing matches from Devereux's (2001) PSID study. ${ }^{16}$

Some facts readily emerge. First, the wages of job changers are always substantially

\footnotetext{
${ }^{14}$ See Solon, Barsky and Parker (1994) and the discussion in Abraham and Haltiwanger, (1995, section $\mathrm{V})$.

${ }^{15}$ The panel studies cover data from 1970 onward and the recession of the 1970s appears to be a particularly procyclical wage episode. The discussion that follows is entirely about wages since the late 1960s, and earlier cycles may be different.

${ }^{16}$ I am grateful to Paul Devereux for making these data available.
} 
Table 4: Estimates of the cyclicality of hourly wages, United States

\begin{tabular}{|c|c|c|c|}
\hline Author & Data & Coefficient on $-\Delta u$ & 100 \\
\hline & NI SY & all (sep whites/nonwh.) & $1.6 / 1.8$ \\
\hline Bils (1985) & 1066 80 & stayers & $0.6 / 0.4$ \\
\hline & & changers & $3.0 / 4.0$ \\
\hline & & all (sep whites/nonwh.) & $1.7 / 1.4$ \\
\hline Shin (1994) & $\begin{array}{l}\text { NLS Y } \\
1066-81\end{array}$ & stayers & $1.2 / 0.2$ \\
\hline & & changers & $2.7 / 3.8$ \\
\hline Dol- : $(0001)$ & PSID, 1968-93 & changers & 2.59 \\
\hline Barlev1 (2001) & NLSY, 1979-93 & changers & 3.00 \\
\hline & & all, cont. $u^{1}$ & 0.7 \\
\hline Beaudry and & PSID & all, initial $u^{2}$ & 0.6 \\
\hline & & all, $\min u^{3}$ & 2.9 \\
\hline Beaudry and & & all, cont. $u^{1}$ & 0.0 \\
\hline Beaudry and & CPS & all, initial $u^{2}$ & 0.0 \\
\hline & 1979,1983 & all, $\min u^{3}$ & 3.1 \\
\hline & & all, cont. $u^{1}$ & 2.37 \\
\hline Grant (2003) & NLSY & all, initial $u^{2}$ & 0.60 \\
\hline & & all, $\min u^{3}$ & 2.29 \\
\hline & & all men & 1.40 \\
\hline NoIOIl, Dalsky allu & IDEe at & all women & 0.53 \\
\hline Parker (1994) & & stayers, men & 1.24 \\
\hline & & all & 1.16 \\
\hline Devereux (2001) & PSID & stayers & 0.81 \\
\hline & & single job holders & 0.54 \\
\hline Shin and & NLSY & all & 1.37 \\
\hline Solon (2006) & 1979-93 & stayers & 1.17 \\
\hline & & single job holders & 1.13 \\
\hline
\end{tabular}

The dependent variable is the annual change in the log of hourly earnings, obtained from the estimated coefficients on annual time dummies in individual wage regressions. Results are for men, unless otherwise stated. Unemployment is national unemployment in percent, except for Barlevi's study, which uses state unemployment. In Beaudry and DiNardo's and Grant's studies the results shown are from regressions with three independent unemployment variables, as follows: 1. contemporraneous unemployment, 2 . unemployment at start of job, 3. lowest unemployment since start of job 
Table 5: Estimates of the cyclicality of hourly wages, Europe

\begin{tabular}{llll} 
Author & Data & \multicolumn{2}{c}{ Coefficient on $-\Delta u \times 100$} \\
\hline \hline Devereux and & UK & stayers (men/women) & $1.93 / 1.93$ \\
Hart (2006) & NESPD (admin.) & movers within co. & $2.28 / 2.31$ \\
& $1975-2001$ & movers between co. & $2.96 / 2.84$ \\
\hline \multirow{2}{*}{ Peng and } & UK & stayers & 2.19 \\
Siebert (2007) & BHPS & movers within co. & 2.27 \\
& $1991-2004$ & movers between co. & 2.89 \\
Peng and & W. Germany & stayers & 1.61 \\
Siebert (2007) & GSOEP & movers within co. & 3.43 \\
& $1984-2002$ & movers between co. & 3.44 \\
\hline \multirow{2}{*}{ Peng and } & N Italy & stayers & 3.60 \\
Siebert (2006) & ECHP & movers within co. & 6.63 \\
& 1994-2001 & movers between co. & 5.61 \\
\hline \multirow{2}{*}{ Carneiro and } & Portugal & stayers (men/women) & $1.20 / 0.85$ \\
Portugal (2007) & QP (admin.) & new hires (no panel) & $2.08 / 1.78$ \\
\hline
\end{tabular}

results for East Germany and South/Central Italy not significant

The dependent variable is the annual change in the log of hourly earnings, obtained from the estimated coefficients on annual time dummies in individual wage regressions. Results are for men, except for the studies of Devereux and Hart and Carneiro and Portugal which report results separately for men and women. The data sets described as (admin.) are based on employer data, the others are from household surveys

more procyclical than the wages of job stayers. The same fact is reflected in studies that draw a distinction between the wages of stayers and the wages of all workers. The wages of all workers are always more procyclical than the wages of job stayers. Second, the wages of job stayers, and even of those who remain in the same job with the same employer (Devereux, 2001, Shin and Solon, 2006), are still mildly procyclical. Perhaps surprisingly, there is more procyclicality in the wages of stayers in Europe than in the United States. The procyclicality of job stayers' wages is sometimes due to bonuses, overtime pay and the like, but it still reflects a rise in the hourly cost of labor to the firm in cyclical peaks.

The cyclical indicator variable used in the panel studies is usually national unemployment, following the lead of Bils (1985). A consensus estimate of the coefficient in wage regressions for job changers is close to 3, i.e., for every percentage point rise in unemployment, the wages in new matches are lower by about $3 \%$. Because no study distinguishes between the wage impact of own productivity, economy-wide productivity 
and labor-market tightness (even if measured only with unemployment), it is not possible to compare each one of the elasticities of the model with the empirical estimates. However, converting the empirical estimates to an overall impact of the cyclical component of hourly productivity on wages gives results that are very close to the model's predictions.

In the model the total elasticity of wages with respect to mean productivity is in the range 0.98 to 1.03 . In order to convert the estimated unemployment elasticities to productivity elasticities, I use annual observations for 1948-2006 for the same unemployment variable as in the panel regressions, and annual observations for the deviation of productivity from trend, to run a simple OLS regression which yields, $\Delta u_{t} / \Delta \ln p_{t-1}=-0.34$. This result is remarkably robust to small changes in specification, such as using the log-change in labor productivity instead of its deviation from HP trend. When the sample is restricted to 1970-1993, as in the panel studies, the coefficient goes up to -0.49 . These estimates appear to confirm a stable "Okun Law" of hourly productivity on unemployment, although usually Okun's Law is between aggregate GDP, which includes the change in hours, and unemployment. Applying the estimated Okun coefficients to convert the estimated cyclical impact on the wages of job changers to a wage-productivity elasticity we find that for a semi-elasticity of 3 , the productivity elasticity of wages is $3 \times 0.34=1.02$, and for the estimates over the $1970-93$ period it is 1.47 . These numbers are very close to the predictions of the model, and if anything, they reveal more cyclicality of wages in the data than in the model.

The cyclicality estimates in the literature are obtained by regressing the coefficients on the time dummies on the change in national unemployment and a linear time trend. However, examination of the data shows that a linear time trend is not necessarily the best approximation to the trend change in wage growth. I HP-filtered Devereux's PSID data shown in Figure 2 and re-ran the second-stage regression, obtaining, for job changers,

$$
\Delta \log w_{t}=\begin{array}{ll}
0.00 & -2.92 \Delta u \\
(0.65)
\end{array} \quad R^{2}=0.51
$$

The coefficient estimate is very similar to the ones obtained in the literature and still slightly above the model prediction. Running a regression with the data in Figure 2, with dependent variable the cyclical component of the change in log wages and independent the cyclical component of the change in log productivity gives an elasticity of 1.7 , well above the one predicted by the model but not significantly different from it. ${ }^{17}$

\footnotetext{
${ }^{17}$ More recently, and too late to fully discuss in this version of the paper, Haefke, Sonntag, and van
} 
Of course, the initial wage is not the only one that matters in the job creation decisions of firms, although it is the main influence. But other evidence also supports the claim that the cost of labor to the firm is procyclical. ${ }^{18}$ The wages of continually employed workers also increase in cyclical peaks, with an estimated unemployment coefficient of $1-1.5$. This implies a wage-productivity elasticity of $0.3-0.5 .{ }^{19}$ Let us suppose that workers hired in recession expect their wages in the future to respond to changes in the state of the economy with the same elasticities as wages in current ongoing matches. The fact that the elasticities in continuing jobs are about half of what they are in new jobs implies that the losses suffered in recession are not immediately reversed. However, this is only indirect evidence for this important property. More direct evidence on this issue was provided by Beaudry and DiNardo (1991).

Beaudry and DiNardo ran the usual set of panel regressions with the PSID and the 1979 and 1982 Pension Supplements of the May CPS, but tried three different kinds of unemployment rates as cyclical indicators. Contemporaneous unemployment, as in the other studies, unemployment at the time of hire and the lowest unemployment rate during the tenure of the job. They found that the dominant influence on wages was exerted by the lowest unemployment rate during the job's tenure. The estimated coefficient on this variable implied a unit wage-productivity elasticity. Grant (2003) replicated their results with a different data set, the various cohorts of the NLS, and also found the strongest influence coming from the lowest unemployment rate since the formation of the match, although contemporaneous unemployment was also significant in his estimates. ${ }^{20}$

This evidence is strongly supportive of the argument that outside labor-market conditions exert a strong and asymmetric influence on wage negotiations, because incumbents' wages respond to the most favorable outside labor-market conditions but do not reverse

Rens (2007) computed a quarterly wage series from the CPS, for matches that originate from nonemployment. Although the results are still preliminary, they also show virtual proportionality between wages and productivity.

${ }^{18} \mathrm{An}$ issue I did not address at all is taxation. If a firm can get more tax breaks in recession, or if overall company taxation is progressive, this gives another reason for procyclicality in labor costs.

${ }^{19}$ Blank (1990) who unlike much of the literature used the percent change in GDP as her cyclical indicator, estimated elasticities of that order of magnitude for repeated cross-sections of the PSID or panels derived from it.

${ }^{20}$ Similar results regarding the lowest past unemployment were obtained by McDonald and Worswick (1999) for Canada and Bell, Nickell and Quintini (2002) for the United Kingdom. Devereux and Hart (2007), using the superior New Earnings Survey Panel Data Set for Britain, find some consistent evidence but also that the spot market is more important than in the original Beaudry and DiNardo study, at least for Britain. 
those gains when labor-market conditions deteriorate. The authors interpret this as evidence in favor of long-term implicit contracts, with the firm shielding wages from adverse outside conditions, and low mobility costs. When outside conditions improve the firm raises wages to stop the workers from quitting.

Yet more evidence supporting the strong procyclicality of wages was found by Blanchflower and Oswald (1994). ${ }^{21}$ They estimated a "wage curve" for industry-aggregated wages across a panel of 19 US manufacturing industries and found that industry profits per employee exert a strong positive influence on total compensation per employee, when controlling for industry and time effects. They interpret this finding as evidence in favor of the bargaining model for wage determination. It implies that there is comovement between the cyclicality of profits and the cyclicality of wages, as in the search and matching model, with the cyclicality in profits driving job creation.

\section{Implications and extensions}

The results of panel regressions contain one clear message: the wages of workers who change jobs during the year are about as cyclical as labor productivity but the wages of those in ongoing jobs are about half as cyclical (in terms of the wage-productivity elasticity). Moreover, wages in ongoing jobs respond more to an improvement in labor market conditions than to a deterioration. The Nash wage equation of search models does not quite match these facts but it matches the most important one: that in equilibrium the wages negotiated in new matches are about as cyclical as productivity. The evidence certainly does not support explanations of the unemployment volatility puzzle that imply substantially less volatility in wages than in productivity. The evidence also does not support the claim that outside conditions do not influence wage bargaining within the firm, either for new matches or for continuing ones.

\footnotetext{
${ }^{21}$ The main objective of Blanchflower and Oswald's (1994) study was to show that there is a "wage curve", a negative relation between real wages and local unemployment. Their main tests use repeated cross sections. Although a wage curve is certainly consistent with the wage equation of the search and matching model, I did not include their study in Table 4 because their evidence is not about hourly wages but about annual earnings, it does not distinguish between stayers and job changers and it does not focus on the cyclical dimension of wages. However, as David Card (1995) in his review of Blanchflower and Oswald points out, their point estimates are consistent with the estimates of the cyclicality literature and provide further support for cyclicality. In estimates by Card (1995, Table 3), hourly wages in the Blanchflower and Oswald samples also exhibit cyclicality for a variety of worker types and, importantly, the unemployment elasticity of wages doubles for workers who had more than one employer during the previous year (when compared with the wages of workers who had the same employer throughout the year).
} 
The Nash wage equation makes the wages of all workers equally responsive to cyclical conditions as their present discounted value. But this is a simplification rather than a necessary ingredient of the model. Small modifications to the equation, that do not influence the job creation or job destruction conditions, can reduce the cyclical responsiveness of wages in ongoing jobs. One such modification was suggested by Beaudry and DiNardo (1991). ${ }^{22}$ Suppose workers are risk averse but firms risk neutral, for the reasons given in the implicit contract models of Azariadis (1975) and Baily (1974). As argued by the implicit contract literature, the risk-neutral firm absorbs all fluctuations in productivity as long as it is jointly rational to continue the job. So once the worker is hired, her wages are not responsive to the cycle. But the firm has no incentive to reduce the cyclicality of the wages of new hires. A modification to this model can increase the cyclicality of wages in ongoing jobs above zero. If workers search on the job and quit to join another firm, the firm has an incentive to raise the wages of those hired in recession when cyclical conditions improve. If it did not raise wages, the workers hired in recession would quit, and it would then need to re-advertise the position and hire new workers at the higher wages. By raising the wages of incumbents the firm achieves the same outcome and avoids the hiring cost of the replacement workers. Applying the Nash solution in a model with these features (risk averse workers and search on the job) yields a wage for new hires that is as cyclical as in the canonical model and one for ongoing jobs that is less cyclical, especially for workers hired in cyclical booms. ${ }^{23}$

Given that the timing of wage payments is not relevant to the job creation and job destruction decisions, we do not lose generality if we continue to use the Nash wage equation for all workers, in the search for an explanation for the unemployment volatility puzzle. Of course, other wage mechanisms may do as well but I will discuss here the implications of some extensions to the model within the Nash framework.

A feature of the canonical model that diminishes the response of job creation to cyclical productivity shocks is the proportional relation between tightness and the cost of positing vacancies. Tightness does two things in the canonical job creation model. It drives job creation through the matching function with elasticity less than one, and changes vacancy posting costs with elasticity one. Suppose there is a positive shock to productivity. Firms post more vacancies at cost $c$ each, but because the duration of

\footnotetext{
${ }^{22}$ See also Arozamena and Centero (2007) for an alternative explanation. Building on the common argument that incumbents with long tenures accumulate job-specific capital, they show that the cyclicality of wages should fall with tenure.

${ }^{23}$ See also Rudanko (2006) for similar resuls in a fully-developed model.
} 
vacancies increases, the average vacancy positing cost rises in proportion to the rise in tightness. This puts a brake on the growth of vacancies. Of course, the original motivation for making the vacancy cost depend on tightness is the realism of the assumption the longer a firm has a vacancy the more it will cost it to fill it. However, some authors (most recently Rotemberg, 2006), have argued that if a firm has more than one vacancy, the cost of posting each vacancy should be a declining function of the number that it posts. This is most intuitive in the case of newspaper ads. Advertising two vacancies does not usually attract twice the fee needed to advertise one, if the advertisement is by the same firm. If average advertising costs fall in a cyclical expansion, the depressing effect of longer vacancy durations on vacancy posting costs is mitigated.

An alternative and simpler specification of vacancy costs is to assume that in addition to the posting cost of the canonical model there is a fixed cost of vacancy posting. For example, it may be a fixed cost of setting up the position; or it may be a cost of interviewing or negotiating with the worker. The important property that needs to be satisfied by this component of costs is that it is independent of tightness. Costs of this kind, which are interpreted as waiting costs, play an important role in enhancing cyclicality in the strategic bargaining model of Hall and Milgrom (2007), although in their model the costs need not be paid. I consider briefly, within the Nash framework of the canonical model, the role of fixed costs that are akin to the Hall and Milgrom negotiating and waiting costs.

Suppose that when the worker arrives the firm pays a fixed fee $H$ before the Nash wage is agreed. For example, it may be a cost of finding out about the worker and making sure that she is suitable for the job. Or it may be a negotiation cost. It is straightforward to show that, in the model with constant job destruction rate, the job creation and wage equations become ${ }^{24}$

$$
\begin{aligned}
\frac{p-w}{r+s} & =\frac{c}{q(\theta)}+H \\
w & =(1-\beta) z+\beta(p+c \theta+q(\theta) \theta H) .
\end{aligned}
$$

The intuition for the first condition is obvious. Job creation entails two costs, the proportional cost $c$ and the fixed cost $H$. The fixed cost increases wages with coefficient $\beta \theta q(\theta)$ because if the negotiation fails, the firm has to pay $H$ when it meets another worker, an event that takes place at rate $\theta q(\theta)$. So, by staying in the match, the worker

\footnotetext{
${ }^{24}$ The extension to the model with endogenous job destruction is straightforward and has no impact on the results derived here for the job finding rate.
} 
Table 6: Model results at different job creation costs

\begin{tabular}{ccccc}
\hline \hline$H$ & $c$ & $\varepsilon_{\theta}$ & $\varepsilon_{w}$ & $\varepsilon_{w}^{*}$ \\
\hline 0 & 0.36 & 3.67 & 0.98 & 0.88 \\
0.1 & 0.27 & 4.18 & 0.99 & 0.97 \\
0.2 & 0.20 & 4.87 & 0.99 & 0.98 \\
0.3 & 0.11 & 5.82 & 1.00 & 1.00 \\
0.4 & 0.02 & 7.25 & 1.01 & 1.01 \\
\hline
\end{tabular}

saves the firm an expected cost $\theta q(\theta) H$, and wages increase by a fraction $\beta$ of that saving by the Nash assumptions. Equations (34) and (35) are solved for the two endogenous variables, $\theta$ and $w$.

Table 6 gives a sample of results for different combinations of the two hiring costs, $c$ and $H$, constructed such that the solutions for $\theta$ and $w$ are in all cases the same as in the model with $H=0$. As before the notation is $\varepsilon_{\theta}$ for the elasticity of $\theta$ with respect to $p$, calculated from

$$
\varepsilon_{\theta}=\frac{1}{\eta} \frac{p-\varepsilon_{w} w}{p-w-(r+s) H}
$$

and $\varepsilon_{w}^{*}$ is the wage elasticity required to raise the $\theta$ elasticity to the data point 7.56 , calculated from

$$
\varepsilon_{w}^{*}=\frac{p}{w}-\varepsilon_{\theta} \frac{\eta[p-w-(r+s) H]}{w} .
$$

It is clear from the Table that as the hiring costs are shifted from the proportional to the fixed component the volatility of job creation increases, whereas the wage elasticity hardly changes. At very small values of the proportional component the observed elasticities are consistent with the data. Since we do not have information how the job creation costs are split between the costs that depend on the duration of vacancies and the costs that do not, we cannot choose one combination over another on the basis of independent evidence. Hall and Milgrom (2007) derive a combination of job creation costs consistent with their strategic bargaining approach that produces results that are very similar to those shown in the bottom two rows of table 6 .

As I have already noted, a higher leisure value $z$ can also increase the cyclicality of wages. But as Costain and Reiter (2006) emphasized, this increases also the responsiveness of unemployment to changes in unemployment compensation to unreasonable levels. At $H=0$, the value of $z$ required to match the $\theta$ elasticity in the data is about 0.85. Compare then the unemployment outcome for two unemployment compensation levels, 0.2 and 0.3 . If the value of leisure is 0.45 , (i.e., centering it on the plausible overall 
value of $z$ of 0.7 ) unemployment at 0.2 is $5.2 \%$ and at 0.3 it is $6.2 \%$. But if the value of leisure is 0.6 , and I recalibrate the model so as to give the sample unemployment mean at $z=0.85$, unemployment at compensation level 0.2 is $4.9 \%$ and at 0.3 it is $7.0 \%$. In other words, the impact of unemployment compensation on unemployment, even at fixed job destruction, doubles. Nickell, Nunziata and Ochel (2005) summarize cross-country econometric evidence and find that a 10 percentage point difference in unemployment compensation is associated with a 1.1 percentage point difference in unemployment. So the canonical model with $z=0.71$ gets it about right, whereas in the case of $z=0.85$ the unemployment difference is too high, as Costain and Reiter note.

Does the model with $H>0$ also suffer from this criticism? The case that matches the $\theta$ elasticity in the data with $z=0.71$ is shown in the bottom row of Table 6 . In this case, unemployment at compensation level 0.2 is $4.75 \%$ and at 0.3 it is $6.6 \%$. The impact is nearly 1.9 percentage points, compared with the Nickell, Nunziata and Ochel estimate of 1.1 .

Thus, although fixed hiring costs improve the cyclical performance of the model, they are probably not the full explanation for the unemployment volatility puzzle. Even small values of fixed costs can match both the job finding elasticity and the wage elasticity but not the unemployment compensation elasticity. I briefly consider three other extensions of the canonical model that increase the cyclical volatility of job creation independently of any wage stickiness. All three, however, suffer from the use of parameters that have no immediate counterpart in readily available data, so their quantitative impact cannot be fully ascertained.

Kennan (2007) argues that if firms are subject to both idiosyncratic and aggregate shocks, the response of job creation to the aggregate shock is enhanced if the worker cannot observe the idiosyncratic shock. When idiosyncratic shocks are not observed the Nash solution to the wage bargain is not applicable, but Kennan considers a generalization to argue that although the wage rate reflects the aggregate shock as in the canonical model, it is set always under the assumption that the idiosyncratic component is low. By following this rule the worker avoids losing the match, which would be an outcome if the realization of the shock was low and she bargained under the assumption that it was high. The key link between the aggregate shock and more volatility is a positive covariance between the aggregate shock and the probability that the idiosyncratic component is high. If more firms move to a high idiosyncratic productivity when the aggregate shock is positive, the increase in average profits caused by the shock is higher 
than in the canonical model, because the wage does not reflect the switch of some firms to the higher idiosyncratic productivity.

The parameter that is needed to ascertain the full quantitative impact of this mechanism is the increase in the probability that the firm will find itself with a high idiosyncratic component in cyclical booms. Kennan shows that even a small change in this probability can have a big impact on the volatility of job creation. But there is no empirical counterpart for it with which it can be compared.

On-the-job search is empirically important and the traditional claim is that its cyclical implications for unemployment are dampening: because of congestion caused by the entry of employed job seekers in the recovery phase, the transition out of unemployment slows down (Pissarides, 1994). But recently Krause and Lubik (2004) and Nagypal (2006), in different models, have argued that on-the-job search can increase the volatility of unemployment. Krause and Lubik derive their results through the interaction of job quality and search intensity. As in Pissarides (1994), in cyclical recoveries more employed job seekers enter the market and the composition of jobs shifts in favor of more productive jobs. But they also assume increased search intensity by employed job seekers and show within the context of a business cycle model that the response of unemployment and tightness to cyclical shocks increases. When there is a positive aggregate shock the quality composition of jobs improves, search intensity increases and so job creation increases. It is important here that the tightness measure that drives job creation and Nash wages is the ratio of vacancies to all job seekers, and not the ratio of vacancies to unemployment. It is also important that employed job seekers have the facility to increase their search intensity by more than unemployed job seekers, an assumption that cannot easily be verified.

Nagypal (2006) argues that on-the-job search activity increases unemployment volatility, because of heterogeneities between employed and unemployed job seekers. The key difference between employed and unemployed job seekers in her model is that employed job seekers have a current situation that is better than the one that unemployed job seekers have. So if an employed job seeker is prepared to give up her current job to accept another it must mean that she likes the new job a lot, and so is likely to have a longer tenure in it than an unemployed job seeker is. Unemployed job seekers are more likely to accept an offer, and this is good for job creation, but employed job seekers are more likely to stay longer when they do accept, which is also good for job creation. Nagypal shows that if there are job creation costs firms prefer the employed job seekers 
because they have longer time periods over which to recover the job creation costs. So, given that in the recovery phase of the cycle more employed workers search for jobs, the response of job vacancies to the recovery is bigger than in the canonical model. However, evaluation of the full quantitative impact of on-the-job search on volatility requires knowledge of preference parameters which cannot be derived from available data.

Another factor that may contribute to more cyclical volatility in unemployment is a nonuniform distribution of the cyclical productivity shocks. First, new jobs may be subject to bigger shocks than existing jobs (see Costain and Reiter, 2005, Reiter, 2006, De Bock, 2006, Eyigungor, 2006). Of course, if all new vacancies reflect the higher productivity, the threat point of workers in new matches adjusts to it too. But two features can increase the volatility of profits when new technology is embodied. First, the size of productivity shocks hitting new jobs is bigger than appears to be from looking at the variance of the average hourly product of labor, because existing jobs get smaller productivity shocks. Second, as noted by Reiter (2006), the worker's outside option varies with the productivity of new jobs, so it is more cyclical than in the canonical model, whereas the outside option of the firm is zero in both models. When a job is being created the worker anticipates a cyclical threat point whereas the firm anticipates acyclical productivity and threat point, and this increases the share of the firm in the peak and reduces it in the trough.

Unemployment also responds more to cyclical shocks when they are not uniformly distributed across industries. The industries that get the large positive shocks create more jobs, but the industries that get the small positive shocks do not destroy more jobs. The reason for the asymmetry is the monopoly rent associated with job matches. Industries that receive smaller positive shocks in the recovery phase can afford to pay higher wages in response to the bigger improvement of conditions elsewhere without shutting the jobs down. The econometric evidence shows that wages in existing matches do not rise by as much as wages in new jobs in the peak, which creates the asymmetry between job creation in the industries that receive the large positive shocks and job destruction in the industries that receive the small shocks.

\section{Conclusions}

The main aim of this paper was to examine the cyclical volatility of wages and its implications for unemployment volatility in the search and matching model. I have shown 
that the cyclical volatility of wages in the canonical search and matching model is about the same as the one estimated for new job matches. It follows that the explanation for the unemployment volatility puzzle - the observation that the response of unemployment to cyclical productivity shocks is much bigger than implied by the canonical model - has to be one that preserves the wage elasticities implied by the canonical model. I discussed some extensions of the canonical model that have this implication, although on closer examination there is as yet no strong support for one of these over all others. The introduction of fixed job creation and negotiating costs, asymmetric information about idiosyncratic shocks, on-the-job search and non-uniform productivity shocks are promising channels which can increase the volatility of unemployment without reducing the volatility of wages.

My focus in this paper was just one cyclical driving force, shocks to the average product of labor. But as in the broader business cycle literature, there is evidence that this is not the only cyclical shock that drives unemployment. The introduction of other cyclical shocks is fairly recent in the search literature and this is another avenue for future work. Demand shocks in particular, with or without sticky prices, are a particularly promising research agenda for an integration of conventional business cycle theory with the recent unemployment volatility literature. ${ }^{25}$

\section{References}

[1] Abraham, K. G. and J. C. Haltiwanger (1995). "Real Wages and the Business Cycle." Journal of Economic Literature 33: 1215-1264.

[2] Andres, J., R. Domenech, and J. Ferri (2006). "Price Rigidity and the Volatility of Vacancies and Unemployment." University of Valencia mimeo.

\footnotetext{
${ }^{25}$ Braun, De Bock and DiCerio (2006) find that there are both technology and demand shocks driving unemployment in their VARs, and Barnichon (2006) shows that the correlations between productivity shocks and unemployment also vary across cycles, which is consistent with the coexistence of productivity and demand shocks. His work also implies that there are endogenous changes in productivity so not all observed changes in productivity are "shocks". Abraham and Haltiwanger (1995) note that the cyclical properties of wages vary across samples, with some cycles exhibiting more demand-side shocks and some others more supply-side shocks. There is a large recent literature on price stickiness in search models that addresses itself mainly to monetary policy and the Phillips curve. Anders, Domenech and Ferri (2006) explore a SDGE version of the search and matching model with a number of different mechanisms for the cycle and conclude that price stickiness is the most potent cause of volatility. For a model with monopolistic firms and volatility driven by changes in price markups see Rotemberg (2006).
} 
[3] Andolfatto, D. (1996). "Business Cycles and Labor Market Search." American Economic Review 86: 112-132.

[4] Arozamena, L. and M. Centeno (2007). "Tenure, Business Cycle and the Wage Setting Process." European Economic Review forthcoming.

[5] Azariadis, C. (1975). "Implicit Contracts and Underemployment Equilibria." Journal of Political Economy 83: 1183-1201.

[6] Baily, N. (1974). "Wages and Employment under Uncertain Demand." Review of Economic Studies 42: 37-50.

[7] Barlevy, G. (2001). "Why are the wages of job clangers so procyclical?" Journal of Labor Economics, 19: 837-78.

[8] Barnichon, R. (2007). "Productivity, Aggregate Demand and Unemployment Fluctuations." LSE mimeo.

[9] Barro, R. J. (1977). "Long-Term Contracting, Sticky Prices, and Monetary Policy." Journal of Monetary Economics 3: 305-316.

[10] Beaudry, P. and J. DiNardo (1991). "The effect of implicit contracts on the movement of wages over the business cycle: Evidence from micro data." Journal of Political Economy, 99: 665-88.

[11] Bell B., S. Nickell and G. Quadrini. (2002). "Wage Equations, Wage Curves and All That." Labour Economics 9: 341-360.

[12] Bils, M. J. (1985). "Real wages over the business cycle: Evidence from panel data." Journal of Political Economy, 93: 666-89.

[13] Blank, R. M. (1990). "Why Are Wages Cyclical in the 1970s?" Journal of Labor Economics 8: 16-47.

[14] Blanchflower, D. G. and A. J. Oswald (1994). The Wage Curve. Cambridge, MA, MIT Press.

[15] Brandolini, A. (1995). "In Search of a Stylised Fact: Do Real Wages Exhibit a Consistent Pattern of Cyclical Variability?" Journal of Economic Surveys 9: 103163. 
[16] Braun, H., R. De Bock, and R. DiCecio. (2006). "Aggregate Shocks and Labor Market Fluctuations." Federal Reserve bank of St. Louis Working Paper no. 2006004A.

[17] Card, D. (1995). "The Wage Curve: A Review." Journal of Economic Literature 33: 785-799.

[18] Carneiro, A. and P. Portugal (2007). "Workers' flows and real wage cyclicality." Institute for the Study of Labor (IZA), Bonn, Discussion Paper 2604.

[19] Costain, J. S. and M. Reiter (2006). "Business Cycles, Unemployment Insurance, and the Calibration of Matching Models." University of Pompeu Fabra mimeo.

[20] Cole, H. and R. Rogerson (1999). "Can the Mortensen-Pissarides Matching Model Match the Business Cycle Facts?" International Economic Review 40: 933-959.

[21] Davis, S. J. and J. C. Haltiwanger (1992). "Gross Job Creation, Gross Job Destruction, and Employment Reallocation." Quarterly Journal of Economics 107: 819-863.

[22] Davis, S. J. and J. C. Haltiwanger (1999). "Gross Job Flows". In Handbook of Labor Economics vol. 3. O. Ashenfelter and D. Card, eds. Amsterdam: North-Holland, 2711-2805.

[23] Davis, S. J., J. C. Haltiwanger, and S. Schuh (1996). Job Creation and Destruction. Cambridge, MA, MIT Press.

[24] De Bock, R. (2006). "Investment-Specific Technology Shocks and Labor Market Frictions." Northwestern University mimeo.

[25] den Haan, W., G. Ramey and J. Watson (2000). "Job Destruction and the Propagation of Shocks." American Economic Review 90: 482-498.

[26] Devereux, P. J. (2001). "The Cyclicality of Real Wages Within Employer-Employee Matches." Industrial and Labor Relations Review, 54: 835-850

[27] Devereux, P. J. and R. A. Hart (2006). "Real Wage Cyclicality of Job Stayers, Within-Company Job Movers, and Between-Company Job Movers." Industrial and Labor Relations Review 60: 105-119. 
[28] Devereux, P. J. and R. A. Hart (2007). "The Spot Market Matters: Evidence on Implicit Contracts from Britain." Scottish Journal of Political Economy forthcoming.

[29] Elsby, M. W., R. Michaels, and G. Solon (2007). "The Ins and Outs of Cyclical Unemployment." NBER Working Paper 12853.

[30] Eyigungor, B. (2006). "Specific Capital and Vintage Effects on the Dynamics of Unemployment and Vacancies." UCLA mimeo.

[31] Farber, H. (1997). "The Changing Face of Job Loss in the United States." Brookings Papers on Economic Activity: Microeconomics: 161-166.

[32] Fujita, S. and G. Ramey (2006). "Reassessing the Shimer Facts" University of California San Diego mimeo.

[33] Grant, D. (2003). "The Effect of Implicit Contracts on the Movement of Wages over the Business Cycle: Evidence from the National Longitudinal Surveys." Industrial and Labor Relations Review, 56: .

[34] Haefke, C., M. Sonntag, and T. van Rens. (2007). "Wage Creation and Job Creation." Unpublished manuscript.

[35] Hagedorn, M. and I. Manovskii (2006). "The Cyclical Behavior of Equilibrium Unemployment and Vacancies Revisited." University of Pennsylvania mimeo.

[36] Hall, R. E. (2005a). "Employment Fluctuations with Equilibrium Wage Stickiness." American Economic Review 95: 50-65.

[37] Hall, R. E. (2005b). "Job Loss, Job Finding, and Unemployment in the U.S. Economy over the Past Fifty Years." NBER Macroeconomics Annual: 101-137.

[38] Hall, R. E. and P. Milgrom (2007). "The Limited Influence of Unemployment on the Wage Bargain." Stanford University mimeo.

[39] Hornstein, A., P. Krusell, and G. L. Violante. (2005). "Unemployment and Vacancy Fluctuations in the Matching Model: Inspecting the Mechanisms." Federal Reserve Bank of Richmond Economic Quarterly 91(3): 19-51. 
[40] Kennan, J. (2007). "Private Information, Wage Bargaining, and Employment Fluctuations." University of Wisconsin-Madison mimeo.

[41] Krause, M. and T. Lubik (2004). "On-the-Job Search and the Cyclical Dynamics of the Labor Market." Johns Hopkins University mimeo.

[42] Langot, F. (1995). "Unemployment and Business Cycle: A General Equilibrium Matching Model." In Advances in Business Cycle Research, ed., P.-Y. Henin. Berlin: Springer, 287-322.

[43] McDonald, J. T. and Worswick, C. (1999). "Wages, Implicit Contracts, and the Business Cycle: Evidence from Canadian Micro Data." Journal of Political Economy 197: 884-892

[44] Merz, M. (1995). "Search in the Labor Market and the Real Business Cycle." Journal of Monetary Economics 36: 269-300.

[45] Mortensen, D. T. and E. Nagypal (2007). "More on Unemployment and Vacancy Fluctuations." Review of Economic Dynamics, forthcoming.

[46] Mortensen, D. T. and C. A. Pissarides (1994). "Job Creation and Job Destruction in the Theory of Unemployment." Review of Economic Studies 61: 397-415.

[47] Nagypal, E. (2005). "Labor-Market Fluctuations, On-the-job Search, and the Acceptance Curse." Northwestern University mimeo.

[48] Peng, F. and W. S. Siebert (2007). "Real Wage Cyclicality in Germany and the UK: New results Using Panel Data." IZA Discussion Paper no. 2688.

[49] Petrongolo, B. and C. A. Pissarides (2001). "Looking into the Black Box: A Survey of the Matching Function." Journal of Economic Literature 39: 390-431.

[50] Pissarides, C. A. (1985). "Short-Run Equilibrium Dynamics of Unemployment, Vacancies, and Real Wages." American Economic Review 75: 676-690.

[51] Pissarides, C. A. (1986). "Unemployment and Vacancies in Britain." Economic Policy 3: 499-559.

[52] Pissarides, C. A. (1994). "Search Unemployment with On-the-job Search." Review of Economic Studies 61: 457-475. 
[53] Pissarides, C. A. (2000). Equilibrium Unemployment Theory. 2nd ed., Cambridge, MA, MIT Press.

[54] Reiter, M. (2006). "Embodied Technical Change and the Fluctuations of Wages and Unemployment." University of Pompeu Fabra Working Paper no. 980.

[55] Rotemberg, J. (2006). "Cyclical Wages in a Search-and-Bargaining Model with Large Firms." CEPR Discussion Paper 5791. London.

[56] Rudanko, L. (2006). "Labor Market Dynamics under Long Term Wage Contracting and Incomplete Markets." University of Chicago mimeo.

[57] Shimer, R. (2004). "The Consequences of Rigid Wages in Search Models." Journal of the European Economic Association (Papers and Proceedings), 2: 469-479.

[58] Shimer, R. (2005a). "The Cyclical Behavior of Equilibrium Unemployment and Vacancies." American Economic Review 95: 25-49.

[59] Shimer, R. (2005b). "Reassessing the Ins and Outs of Unemployment." University of Chicago mimeo.

[60] Shin, D. (1994). "Cyclicality of Real Wages Among Young Men." Economics Letters, 46: $137-142$.

[61] Shin, D. and G. Solon. (2006). "New Evidence on Real Wage Cyclicality Within Employer-Employee Matches." National Bureau of Economic Research Working Paper no. 12262.

[62] Solon, G., R. Barsky, and J. A. Parker. (1994). "Measuring the Cyclicality of Real Wages: How Important is Composition Bias?" Quarterly Journal of Economics, 109: $1-25$.

[63] Yashiv, E. (2006). "Evaluating the Performance of the Search and Matching Model." European Economic Review 50: 909-936.

[64] Yashiv, E. (2007). "Labor Search and Matching in Macroeconomics." IZA Discussion Paper. Bonn. 
Figure 1

The contribution of the job finding and job separation rates to changes in unemployment

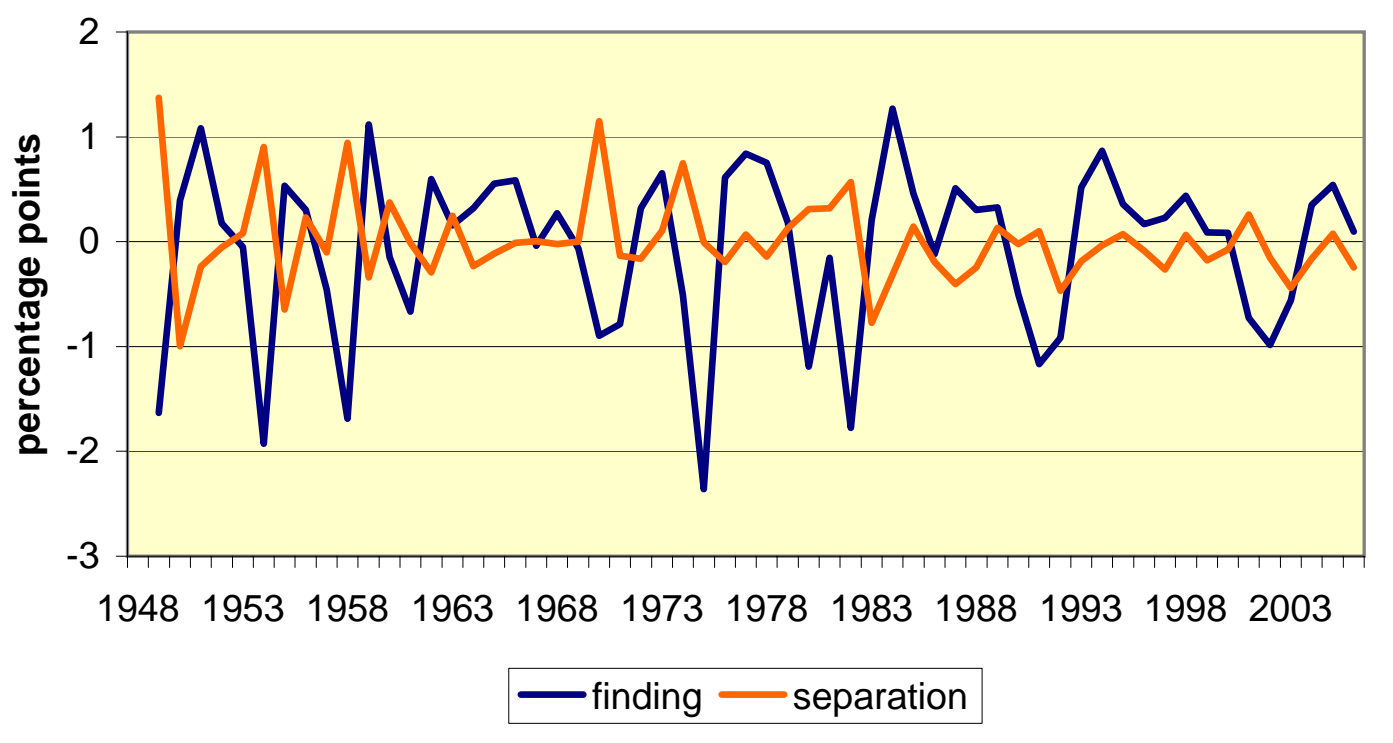

Figure 2

Cyclical wage and producitivty changes

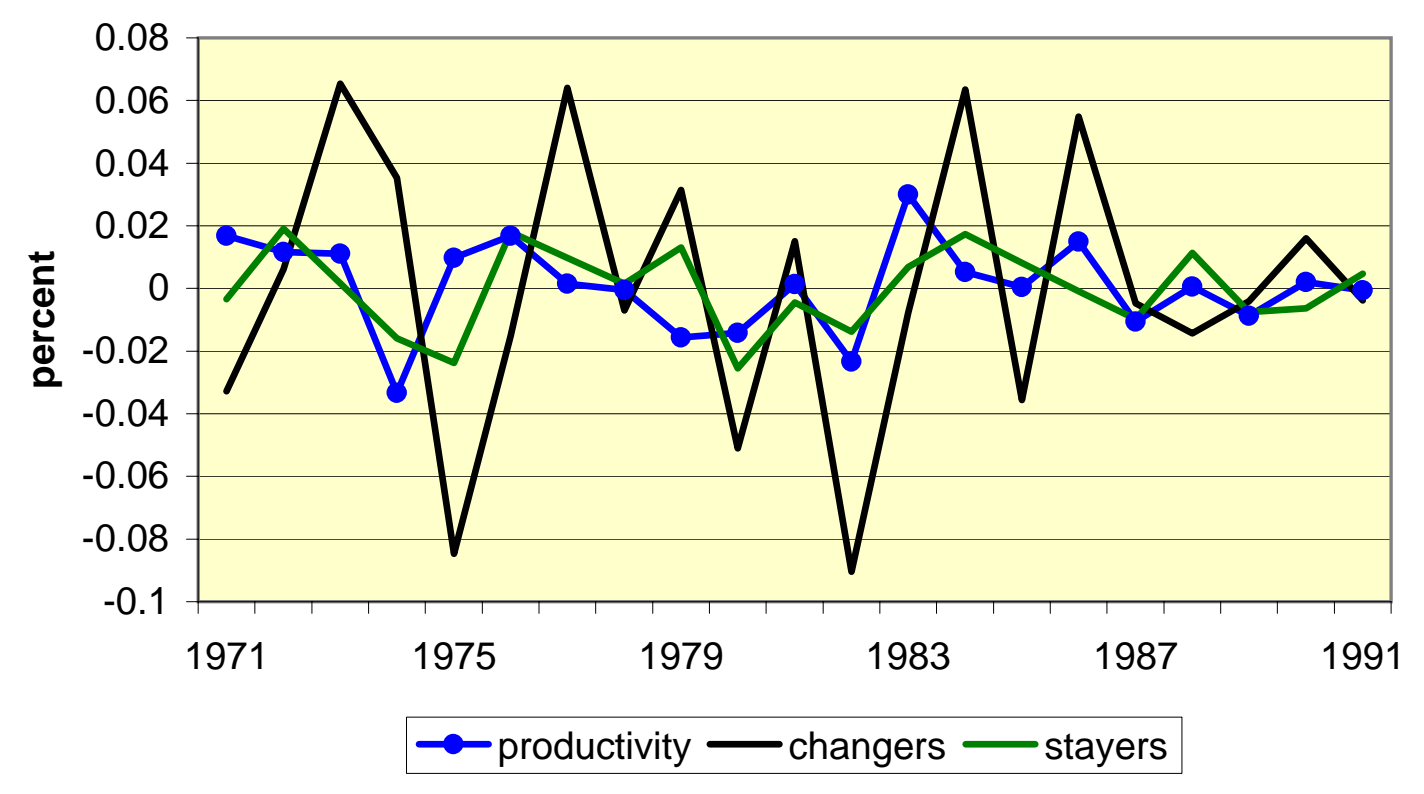




\section{CENTRE FOR ECONOMIC PERFORMANCE Recent Discussion Papers}

\begin{tabular}{|c|c|c|}
\hline 838 & Kevin D. Sheedy & $\begin{array}{l}\text { Inflation Persistence when Price Stickiness } \\
\text { Differs between Industries }\end{array}$ \\
\hline 837 & Kevin D. Sheedy & Intrinsic Inflation Persistence \\
\hline 836 & $\begin{array}{l}\text { Andrew E. Clark } \\
\text { Ed Diener } \\
\text { Yannis Georgellis } \\
\text { Richard E. Lucas }\end{array}$ & $\begin{array}{l}\text { Lags and Leads in Life Satisfaction: A Test of } \\
\text { the Baseline Hypothesis }\end{array}$ \\
\hline 835 & Jean-Baptiste Michau & Creative Destruction with On-the-Job Search \\
\hline 834 & Nikolaus Wolf & $\begin{array}{l}\text { Scylla and Charybodis: the European Economy } \\
\text { and Poland's Adherence to Gold, 1928-1936 }\end{array}$ \\
\hline 833 & $\begin{array}{l}\text { Sharon Belenzon } \\
\text { Tomer Berkovitz }\end{array}$ & Innovation in Business Groups \\
\hline 832 & $\begin{array}{l}\text { Espen R. Moen } \\
\text { Åsa Rosén }\end{array}$ & Incentives in Competitive Search Equilibrium \\
\hline 831 & Eran Yashiv & U.S. Labor Market Dynamics Revisited \\
\hline 830 & $\begin{array}{l}\text { Laura Alfaro } \\
\text { Andrew Charlton }\end{array}$ & $\begin{array}{l}\text { Growth and the Quality of Foreign Direct } \\
\text { Investment: Is All FDI Equal? }\end{array}$ \\
\hline 829 & $\begin{array}{l}\text { Richard Layard } \\
\text { David Clark } \\
\text { Martin Knapp } \\
\text { Guy Mayraz }\end{array}$ & Cost-Benefit Analysis of Psychological Therapy \\
\hline 828 & Emma Tominey & $\begin{array}{l}\text { Maternal Smoking During Pregnancy and Early } \\
\text { Child Outcomes }\end{array}$ \\
\hline 827 & $\begin{array}{l}\text { Christos Genakos } \\
\text { Tommaso Valletti }\end{array}$ & $\begin{array}{l}\text { Testing the "Waterbed" Effect in Mobile } \\
\text { Telephony }\end{array}$ \\
\hline 826 & $\begin{array}{l}\text { Luis Garicano } \\
\text { Paul Heaton }\end{array}$ & $\begin{array}{l}\text { Information Technology, Organization, and } \\
\text { Productivity in the Public Sector: Evidence from } \\
\text { Police Departments }\end{array}$ \\
\hline 825 & $\begin{array}{l}\text { Laura Alfaro } \\
\text { Andrew Charlton }\end{array}$ & Intra-Industry Foreign Direct Investment \\
\hline 824 & $\begin{array}{l}\text { Miklós Koren } \\
\text { Silvana Tenreyro }\end{array}$ & Technological Diversification \\
\hline
\end{tabular}


823

Régis Barnichon

822 Carlos Thomas

821 Giulia Faggio Kjell G. Salvanes John Van Reenen

820 Luis Araujo Emanuel Ornelas

819 Régis Barnichon

818 Rachel Griffith Sokbae Lee John Van Reenen

817 Tsutomu Miyagawa YoungGak Kim

816 Andreas Georgiadis Alan Manning

815 Guy Michaels Xiaojia Zhi

814 Ralph Ossa

813 Karsten Kohn Alexander C. Lembcke

812 Yannis M. Ioannides Henry G. Overman Esteban Rossi-Hansberg Kurt Schmidheiny

811 Guy Michaels

810 Maia Güell Jose V. Rodriguez Mora Chris Telmer

809 Stephen J. Redding Daniel M. Sturm Nikolaus Wolf
The Shimer Puzzle and the Correct Identification of Productivity Shocks

Search Frictions, Real Rigidities and Inflation Dynamics

The Evolution of Inequality in Productivity and Wages: Panel Data Evidence

Trust-Based Trade

Productivity, Aggregate Demand and Unemployment Fluctuations

Is Distance Dying at Last? Falling Home Bias in Fixed Effects Models of Patent Citations

Measuring Organization Capital in Japan: An Empirical Assessment Using Firm-Level Data

Spend It Like Beckham? Inequality and Redistribution in the UK, 1983-2004

Freedom Fries

Trade Liberalization, Outsourcing, and Firm Productivity

Wage Distributions by Bargaining Regime: Linked Employer-Employee Data Evidence from Germany

The Effect of Information and Communication Technologies on Urban Structure

The Division of Labor, Coordination, and the Demand for Information Processing

Intergenerational Mobility and the Informative Content of Surnames

History and Industry Location: Evidence from German Airports

The Centre for Economic Performance Publications Unit Tel 02079557673 Fax 02079557595 Email info@cep.lse.ac.uk Web site http://cep.lse.ac.uk 